\title{
Effects of BA.1/BA.2 subvariant, vaccination, and prior infection on infectiousness of SARS-CoV-2 Omicron infections
}

Suelen H. Qassim, MBBS MPH ${ }^{1,2}$, Hiam Chemaitelly, $\mathrm{PhD}^{1,2,3}$, Houssein H. Ayoub, $\mathrm{PhD}^{4}$, Sawsan AlMukdad, MSc ${ }^{1,2}$, Patrick Tang, MD PhD ${ }^{5}$, Mohammad R. Hasan, $\mathrm{PhD}^{5}$, Hadi M. Yassine, PhD ${ }^{6,7}$, Hebah A. Al-Khatib, PhD ${ }^{6,7}$, Maria K. Smatti, MSc ${ }^{6,7}$, Hanan F. Abdul-Rahim, $\mathrm{PhD}^{8}$, Gheyath K. Nasrallah, $\mathrm{PhD}^{6,7}$, Mohamed Ghaith Al-Kuwari, MD ${ }^{9}$, Abdullatif Al-Khal, $\mathrm{MD}^{10}$, Peter Coyle, MD ${ }^{6,10,11}$, Anvar Hassan Kaleeckal, $\mathrm{MSc}^{10}$, Riyazuddin Mohammad Shaik, $\mathrm{MSc}^{10}$, Ali Nizar Latif, MD ${ }^{10}$, Einas Al-Kuwari, $\mathrm{MD}^{10}$, Andrew Jeremijenko, $\mathrm{MD}^{10}$, Adeel A. Butt, MBBS MS ${ }^{3,10,12}$, Roberto Bertollini, MD MPH ${ }^{13}$, Hamad Eid Al-Romaihi, MD ${ }^{13}$, Mohamed H. Al-Thani, MD ${ }^{13}$, and Laith J. Abu-Raddad, $\mathrm{PhD}^{1,2,3,8^{*}}$

${ }^{1}$ Infectious Disease Epidemiology Group, Weill Cornell Medicine-Qatar, Cornell University, Doha, Qatar

${ }^{2}$ World Health Organization Collaborating Centre for Disease Epidemiology Analytics on HIV/AIDS, Sexually Transmitted Infections, and Viral Hepatitis, Weill Cornell Medicine-Qatar, Cornell University, Qatar Foundation - Education City, Doha, Qatar

${ }^{3}$ Department of Population Health Sciences, Weill Cornell Medicine, Cornell University, New York, New York, USA

${ }^{4}$ Mathematics Program, Department of Mathematics, Statistics, and Physics, College of Arts and Sciences, Qatar University, Doha, Qatar

${ }^{5}$ Department of Pathology, Sidra Medicine, Doha, Qatar

${ }^{6}$ Biomedical Research Center, Member of QU Health, Qatar University, Doha, Qatar

${ }^{7}$ Department of Biomedical Science, College of Health Sciences, Member of QU Health, Qatar University, Doha, Qatar

${ }^{8}$ Department of Public Health, College of Health Sciences, QU Health, Qatar University, Doha, Qatar

${ }^{9}$ Primary Health Care Corporation, Doha, Qatar

${ }^{10}$ Hamad Medical Corporation, Doha, Qatar

${ }^{11}$ Wellcome-Wolfson Institute for Experimental Medicine, Queens University, Belfast, United Kingdom

${ }^{12}$ Department of Medicine, Weill Cornell Medicine, Cornell University, New York, New York, USA

${ }^{13}$ Ministry of Public Health, Doha, Qatar

Word count: Abstract: 268 words, Main Text: 1,670 words.

Number of tables: 4 .

Number of figures: 2 .

Keywords: COVID-19; Omicron; subvariant; sub-lineage; vaccine; breakthrough infection; cohort study; immunity; epidemiology.

*Correspondence to Professor Laith J. Abu-Raddad, E-mail: lja2002@qatar-med.cornell.edu. 
medRxiv preprint doi: https://doi.org/10.1101/2022.03.02.22271771; this version posted March 4, 2022. The copyright holder for this preprint (which was not certified by peer review) is the author/funder, who has granted medRxiv a license to display the preprint in perpetuity.

All rights reserved. No reuse allowed without permission.

\begin{abstract}
BACKGROUND: Qatar experienced a large SARS-CoV-2 Omicron (B.1.1.529) wave that started on December 19, 2021 and peaked in mid-January, 2022. We investigated effects of Omicron subvariant (BA.1 and BA.2), previous vaccination, and prior infection on infectiousness of Omicron infections, between December 23, 2021 and February 20, 2022.

METHODS: Univariable and multivariable regression analyses were conducted to estimate the association between the RT-qPCR cycle threshold $(\mathrm{Ct})$ value of PCR tests (a proxy for SARSCoV-2 infectiousness) and each of the Omicron subvariants, mRNA vaccination, prior infection, reason for RT-qPCR testing, calendar week of RT-qPCR testing (to account for phases of the rapidly evolving Omicron wave), and demographic factors.
\end{abstract}

RESULTS: Compared to BA.1, BA.2 was associated with 3.53 fewer cycles (95\% CI: 3.463.60), signifying higher infectiousness. Ct value decreased with time since second and third vaccinations. $\mathrm{Ct}$ values were highest for those who received their boosters in the month preceding the RT-qPCR test -0.86 cycles (95\% CI: $0.72-1.00)$ higher than for unvaccinated persons. Ct value was 1.30 (95\% CI: 1.20-1.39) cycles higher for those with a prior infection compared to those without prior infection, signifying lower infectiousness. Ct value declined gradually with age. Ct value was lowest for those who were tested because of symptoms and was highest for those who were tested for travel-related purposes. $\mathrm{Ct}$ value was lowest during the exponential-growth phase of the Omicron wave and was highest after the wave peaked and was declining.

CONCLUSIONS: The BA.2 subvariant appears substantially more infectious than the BA.1 subvariant. This may reflect higher viral load and/or longer duration of infection, thereby explaining the rapid expansion of this subvariant in Qatar. 
medRxiv preprint doi: https://doi.org/10.1101/2022.03.02.22271771; this version posted March 4, 2022. The copyright holder for this preprint (which was not certified by peer review) is the author/funder, who has granted medRxiv a license to display the preprint in perpetuity.

\section{Introduction}

Qatar experienced a large severe acute respiratory syndrome coronavirus 2 (SARS-CoV-2)

Omicron (B.1.1.529) ${ }^{1}$ wave that started on December 19, 2021 and peaked in mid-January, 2022..$^{2-5}$ We investigated effects of Omicron subvariant (BA.1 and BA.2), previous vaccination, and prior infection on infectiousness of Omicron infections, between December 23, 2021 and February 20, 2022. Incidence was initially dominated by BA.1, but within a few days, BA.2 predominated (Figure 1). Incidence of the Delta variant was minimal and no other variants were detected in viral genome sequencing and real-time reverse-transcription polymerase chain reaction (RT-qPCR) genotyping of randomly collected samples (Section S1 of Supplementary Appendix).

\section{Methods}

\section{Study population, data sources, and study design}

The RT-qPCR cycle threshold $(\mathrm{Ct})$ value is a measure of the inverse of viral load and correlates strongly with culturable virus; ${ }^{6}$ thus, it can be used as a proxy for SARS-CoV-2 infectiousness. ${ }^{6-}$

${ }^{11}$ We investigated several effects on the RT-qPCR Ct value of Omicron variant infections in the resident population of Qatar using a cross-sectional study design. These included: subvariant (BA.1 versus BA.2), mRNA (BNT162b2 ${ }^{12}$ and mRNA-1273 ${ }^{13}$ ) vaccination status, prior infection status, reason for RT-qPCR testing, study-period week of the RT-qPCR test (to account for the evolving phase of the rapid Omicron wave), and demographic factors including sex, age, and nationality.

The study population included all individuals with an RT-qPCR-confirmed SARS-CoV-2 infection in Qatar between December 23, 2021 and February 20, 2022. Coronavirus disease 2019 
medRxiv preprint doi: https://doi.org/10.1101/2022.03.02.22271771; this version posted March 4, 2022. The copyright holder for this preprint (which was not certified by peer review) is the author/funder, who has granted medRxiv a license to display the preprint in perpetuity.

All rights reserved. No reuse allowed without permission.

(COVID-19) laboratory testing, vaccination, clinical infection, and demographic data for this population were extracted from the national, federated SARS-CoV-2 databases, which include all RT-qPCR testing, reason for RT-qPCR testing, COVID-19 vaccinations, and related demographic details since the start of the pandemic. Further description of Qatar's national COVID-19 databases can be found in previous publications. ${ }^{11,14-17}$

Every SARS-CoV-2 RT-qPCR test conducted in Qatar is classified based on the reason for testing (clinical symptoms, contact tracing, surveys or random testing campaigns, individual requests, routine healthcare testing, pre-travel, at port of entry, or other). RT-qPCR testing is performed at a mass scale. ${ }^{15}$ About $75 \%$ of those diagnosed over recent months were diagnosed not because of appearance of symptoms, but because of routine testing. ${ }^{15}$ Qatar has unusually young, diverse demographics, in that only $9 \%$ of its residents are $\geq 50$ years of age, and $89 \%$ are expatriates from over 150 countries. ${ }^{14,18}$ Nearly all individuals were vaccinated in Qatar, however, vaccinations performed elsewhere were still recorded in the health system at the port of entry upon arrival to Qatar per country requirements.

Informed by the viral genome sequencing and the RT-qPCR genotyping (Section S1), a SARSCoV-2 infection with the BA.1 subvariant was proxied as an S-gene "target failure" (SGTF) case using the TaqPath COVID-19 Combo Kit (Thermo Fisher Scientific, USA ${ }^{19}$ ) that tests for the Sgene and is affected by the del69/70 mutation in the S-gene. ${ }^{20}$ A SARS-CoV-2 infection with the BA.2 subvariant was proxied as a non-SGTF case using this TaqPath Kit. For ascertainment of subvariant status and standardization of RT-qPCR Ct values, we analyzed only the RT-qPCRconfirmed infections diagnosed with this TaqPath Kit.

For each individual, we selected only the first positive RT-qPCR-confirmed swab during the study period. We subsequently derived a summary measure for our primary outcome, the RT- 
qPCR Ct value, by averaging the $\mathrm{Ct}$ values of the $\mathrm{N}, \mathrm{ORF} 1 \mathrm{ab}$, and $\mathrm{S}$ (if not an S-gene "target failure" case) genes. This average Ct value was used as the dependent variable in all analyses.

Both vaccination status and prior infection status were ascertained at the time of the RT-qPCR test. Vaccination status was defined factoring the number of administered vaccine doses and months elapsed since the last vaccine dose, with one month defined as 30 days. Only vaccination with BNT162b2 $2^{12}$ and mRNA- $1273^{13}$ vaccines were considered in the analyses, as these have been the vaccines of choice in the COVID-19 immunization program in Qatar. ${ }^{21-23}$ Rare occurrences of mixed vaccination regimens were excluded. Prior infection was defined as an RTqPCR-positive test that occurred $\geq 90$ days before the study RT-qPCR-positive test. ${ }^{3,17,24-31}$ An RT-qPCR-positive test that occurred $<90$ days prior to the study RT-qPCR-positive test was still factored in the analysis, but was not considered a prior infection. This is because this RT-qPCRpositive test and the study RT-qPCR-positive test may both reflect the same prolonged infection. ${ }^{32-34}$ A small number of RT-qPCR tests had no recorded $\mathrm{Ct}$ value and were thus excluded from the analysis, but these constituted only $0.1 \%$ of all RT-qPCR tests. Otherwise, data on the remaining study variables were complete.

\section{Oversight}

Hamad Medical Corporation and Weill Cornell Medicine-Qatar Institutional Review Boards approved this retrospective study with waiver of informed consent. The study was reported following STROBE guidelines. The STROBE checklist is found in Table S1.

\section{Statistical analysis}

Frequency distributions and measures of central tendency were used to describe the study population with respect to a priori determined factors. These included Omicron infection 
medRxiv preprint doi: https://doi.org/10.1101/2022.03.02.22271771; this version posted March 4, 2022. The copyright holder for this preprint (which was not certified by peer review) is the author/funder, who has granted medRxiv a license to display the preprint in perpetuity.

All rights reserved. No reuse allowed without permission.

subvariant, vaccination status (factoring dose number and months since vaccination), prior infection status, reason for RT-qPCR testing, study-period week of the RT-qPCR test, and demographic factors, namely sex, age, and nationality. Differences between BA.1 and BA.2 infections were estimated using standardized mean differences (SMDs).

Association of each of these factors with $\mathrm{Ct}$ value was assessed using univariable linear regression analyses. Unadjusted $\beta$ coefficients, 95\% confidence intervals (CIs), and the F-test of overall covariate significance were reported. Adjusted $\beta$ coefficients and associated $95 \%$ CIs and p-values were estimated using multivariable linear regression analyses that included all covariates in the model.

The 95\% CIs were not adjusted for multiplicity. Two-sided $p$-value $<0.05$ indicated statistical significance. Interactions were not considered. Statistical analyses were conducted in STATA/SE version $16 . .^{35}$

\section{Results}

Figure 2 shows the process of selecting the study population and Table 1 describes the study population characteristics. This was a national study involving 156,202 individuals infected with Omicron who are broadly representative of the population of Qatar.

Compared to BA.1, BA.2 was associated with 3.53 fewer cycles (95\% CI: 3.46-3.60), signifying higher infectiousness (Table 2). Ct value decreased with time since second and third vaccinations, mirroring the established pattern of waning vaccine effectiveness. ${ }^{4} \mathrm{Ct}$ values were highest for those who received their boosters in the month preceding the RT-qPCR test -0.86 cycles (95\% CI: 0.72-1.00) higher than for unvaccinated persons. Ct value was 1.30 (95\% CI: 
medRxiv preprint doi: https://doi.org/10.1101/2022.03.02.22271771; this version posted March 4, 2022. The copyright holder for this preprint (which was not certified by peer review) is the author/funder, who has granted medRxiv a license to display the preprint in perpetuity.

All rights reserved. No reuse allowed without permission.

1.20-1.39) cycles higher for those with a prior infection compared to those without prior infection, signifying lower infectiousness.

Ct value declined gradually with age (Table 2), perhaps reflecting slower virus clearance with aging. There were differences in $\mathrm{Ct}$ value by sex and nationality, but these may reflect different test-seeking behaviors for different socio-economic groups in Qatar's diverse population, or differences in the rates of prior undocumented infection by nationality. ${ }^{14,36-39} \mathrm{Ct}$ value was lowest for those who were tested because of symptoms and was highest for those who were tested for travel-related purposes. Ct value was lowest during the exponential-growth phase of the Omicron wave, as a large proportion of infections were recent, and was highest after the wave peaked and was declining, as a small proportion of infections were recent. Stratified analyses for each of BA.1 (Table 3) and BA.2 (Table 4) showed similar findings.

\section{Discussion}

The BA. 2 subvariant appears substantially more infectious than the BA.1 subvariant, consistent with recent findings of a household study from Denmark. ${ }^{40}$ This may reflect higher viral load and/or longer duration of infection, thereby explaining the rapid expansion of this subvariant in Qatar (Figure 1). Natural immunity from previous infection and strength of vaccine immunity correlate with less infectious breakthrough infections, as observed for earlier SARS-CoV-2 variants. ${ }^{11}$ Symptomatic infection and older age are associated with higher infectiousness.

\section{Limitations and caveats}

A small number of RT-qPCR tests had no available $\mathrm{Ct}$ value and were thus excluded from the analysis, but these constituted only $0.1 \%$ of all RT-qPCR tests. The study was implemented on documented RT-qPCR-confirmed infections, but other infections may have occurred but were 
medRxiv preprint doi: https://doi.org/10.1101/2022.03.02.22271771; this version posted March 4, 2022. The copyright holder for this preprint (which was not certified by peer review) is the author/funder, who has granted medRxiv a license to display the preprint in perpetuity.

All rights reserved. No reuse allowed without permission.

never documented. It is possible that infections in those with prior infection or those vaccinated are less likely to be diagnosed, perhaps because of minimal or no symptoms. Nevertheless, RTqPCR testing in Qatar is done at a mass scale, where a significant proportion of the population is being tested every week. ${ }^{15}$ The majority of infections are identified not because of symptoms, but because of routine testing for other reasons (Table 1$).{ }^{15}$ The date of symptom onset was not available for symptomatic cases. Therefore, an analysis factoring the duration between symptom onset and RT-qPCR test was not possible.

The study population consists of mostly working-age adults and thus the results may not necessarily be generalizable to other population groups, such as the elderly. The analyses controlled for sex, age, and nationality but it was not possible to control for other factors, such as comorbidities or socio-economic factors, as data on these factors were not available. Of note that the number of individuals with severe chronic conditions is small in Qatar's young population. ${ }^{14,41}$ The national list of vaccine prioritization included only 19,800 individuals of all age groups with serious co-morbid conditions to be prioritized in the first phase of vaccine rollout. ${ }^{15}$ Factoring nationality in the analyses may have (partially) controlled socio-economic differences/occupational risk, in consideration of the association between nationality and occupation in Qatar. ${ }^{14,36-39}$

BA. 1 and BA. 2 ascertainment was based on proxy criteria; presence or absence of SGTF using the TaqPath Kit, but this method of ascertainment is well established not only for Omicron subvariants, but also for other variants such as Alpha. ${ }^{20,30,42}$ Some Omicron infections may have been misclassified Delta infections, but this is not likely, as Delta incidence was limited during the study (Section S1). 
medRxiv preprint doi: https://doi.org/10.1101/2022.03.02.22271771; this version posted March 4, 2022. The copyright holder for this preprint (which was not certified by peer review) is the author/funder, who has granted medRxiv a license to display the preprint in perpetuity.

All rights reserved. No reuse allowed without permission.

Time since vaccination was associated with lower $\mathrm{Ct}$ value, mirroring the established pattern of waning vaccine effectiveness. ${ }^{4}$ Unexpectedly, however, the $\mathrm{Ct}$ value for those who had their second dose $>6$ months earlier was lower than that among unvaccinated persons. With the high vaccine coverage in Qatar (exceeding 85\%), the unvaccinated group may be different in other uncontrolled attributes from the vaccinated group. For example, those unvaccinated may have chosen not to receive the vaccine because of undocumented prior infection and thus are not truly immune naïve. 
medRxiv preprint doi: https://doi.org/10.1101/2022.03.02.22271771; this version posted March 4, 2022. The copyright holder for this preprint (which was not certified by peer review) is the author/funder, who has granted medRxiv a license to display the preprint in perpetuity.

All rights reserved. No reuse allowed without permission.

\section{Acknowledgements}

We acknowledge the many dedicated individuals at Hamad Medical Corporation, the Ministry of Public Health, the Primary Health Care Corporation, the Qatar Biobank, Sidra Medicine, and Weill Cornell Medicine - Qatar for their diligent efforts and contributions to make this study possible.

The authors are grateful for support from the Biomedical Research Program and the Biostatistics, Epidemiology, and Biomathematics Research Core, both at Weill Cornell Medicine-Qatar, as well as for support provided by the Ministry of Public Health, Hamad Medical Corporation, and Sidra Medicine. The authors are also grateful for the Qatar Genome Programme and Qatar University Biomedical Research Center for institutional support for the reagents needed for the viral genome sequencing. Statements made herein are solely the responsibility of the authors. The funders of the study had no role in study design, data collection, data analysis, data interpretation, or writing of the article.

\section{Author contributions}

SHQ co-designed the study, performed the statistical analyses, and co-wrote the first draft of the article. HC co-designed the study, supported the statistical analyses, and co-wrote the first draft of the article. LJA conceived and co-designed the study, led the statistical analyses, and co-wrote the first draft of the article. PT and MRH conducted the multiplex, RT-qPCR variant screening and viral genome sequencing. HY, HAK, and MS conducted viral genome sequencing. All authors contributed to data collection and acquisition, database development, discussion and interpretation of the results, and to the writing of the manuscript. All authors have read and approved the final manuscript. 
medRxiv preprint doi: https://doi.org/10.1101/2022.03.02.22271771; this version posted March 4, 2022. The copyright holder for this preprint

(which was not certified by peer review) is the author/funder, who has granted medRxiv a license to display the preprint in perpetuity.

All rights reserved. No reuse allowed without permission.

\section{Competing interests}

Dr. Butt has received institutional grant funding from Gilead Sciences unrelated to the work presented in this paper. Otherwise we declare no competing interests. 
medRxiv preprint doi: https://doi.org/10.1101/2022.03.02.22271771; this version posted March 4, 2022. The copyright holder for this preprint (which was not certified by peer review) is the author/funder, who has granted medRxiv a license to display the preprint in perpetuity.

All rights reserved. No reuse allowed without permission.

\section{References}

1. World Health Organization. Tracking SARS-CoV-2 variants. Available from:

https://www.who.int/en/activities/tracking-SARS-CoV-2-variants/. 2021.

2. Qatar viral genome sequencing data. Data on randomly collected samples.

https://www.gisaid.org/phylodynamics/global/nextstrain/. 2021. at https://www.gisaid.org/phylodynamics/global/nextstrain/.)

3. Altarawneh HN, Chemaitelly H, Hasan MR, et al. Protection against the Omicron Variant from Previous SARS-CoV-2 Infection. N Engl J Med 2022.

4. Chemaitelly H, Ayoub HH, AlMukdad S, et al. Duration of protection of BNT162b2 and mRNA-1273 COVID-19 vaccines against symptomatic SARS-CoV-2 Omicron infection in Qatar. medRxiv 2022:2022.02.07.22270568.

5. Chemaitelly H, Ayoub HH, Coyle P, et al. Protection of Omicron sub-lineage infection against reinfection with another Omicron sub-lineage. medRxiv 2022:2022.02.24.22271440.

6. Singanayagam A, Patel M, Charlett A, et al. Duration of infectiousness and correlation with RT-PCR cycle threshold values in cases of COVID-19, England, January to May 2020. Euro Surveill 2020;25.

7. Lyngse FP, Mølbak K, Træholt Franck K, et al. Association between SARS-CoV-2 Transmissibility, Viral Load, and Age in Households. medRxiv 2021:2021.02.28.21252608.

8. Lee LYW, Rozmanowski S, Pang M, et al. SARS-CoV-2 infectivity by viral load, S gene variants and demographic factors and the utility of lateral flow devices to prevent transmission. Clin Infect Dis 2021.

9. Marks M, Millat-Martinez P, Ouchi D, et al. Transmission of COVID-19 in 282 clusters in Catalonia, Spain: a cohort study. Lancet Infect Dis 2021;21:629-36.

10. Bullard J, Dust K, Funk D, et al. Predicting Infectious Severe Acute Respiratory Syndrome Coronavirus 2 From Diagnostic Samples. Clin Infect Dis 2020;71:2663-6.

11. Abu-Raddad LJ, Chemaitelly H, Ayoub HH, et al. Relative infectiousness of SARS-CoV2 vaccine breakthrough infections, reinfections, and primary infections. Nat Commun 2022;13:532.

12. Polack FP, Thomas SJ, Kitchin N, et al. Safety and Efficacy of the BNT162b2 mRNA Covid-19 Vaccine. N Engl J Med 2020;383:2603-15.

13. Baden LR, El Sahly HM, Essink B, et al. Efficacy and Safety of the mRNA-1273 SARSCoV-2 Vaccine. N Engl J Med 2021;384:403-16.

14. Abu-Raddad LJ, Chemaitelly H, Ayoub HH, et al. Characterizing the Qatar advancedphase SARS-CoV-2 epidemic. Sci Rep 2021;11:6233.

15. Chemaitelly H, Tang P, Hasan MR, et al. Waning of BNT162b2 Vaccine Protection against SARS-CoV-2 Infection in Qatar. N Engl J Med 2021;385:e83.

16. Tang P, Hasan MR, Chemaitelly H, et al. BNT162b2 and mRNA-1273 COVID-19 vaccine effectiveness against the SARS-CoV-2 Delta variant in Qatar. Nat Med 2021;27:213643.

17. Chemaitelly H, Bertollini R, Abu-Raddad LJ, National Study Group for Covid Epidemiology. Efficacy of Natural Immunity against SARS-CoV-2 Reinfection with the Beta Variant. N Engl J Med 2021;385:2585-6.

18. Planning and Statistics Authority-State of Qatar. Qatar Monthly Statistics. Available from: https://www.psa.gov.qa/en/pages/default.aspx. Accessed on: May 26, 2020. 2020.

19. Thermo Fisher Scientific. TaqPath ${ }^{\mathrm{TM}}$ COVID-19 CE-IVD RT-PCR Kit instructions for use. Available from: https://assets.thermofisher.com/TFS- 
medRxiv preprint doi: https://doi.org/10.1101/2022.03.02.22271771; this version posted March 4, 2022. The copyright holder for this preprint (which was not certified by peer review) is the author/funder, who has granted medRxiv a license to display the preprint in perpetuity.

All rights reserved. No reuse allowed without permission.

Assets/LSG/manuals/MAN0019215_TaqPathCOVID-19_CE-IVD_RT-PCR\%20Kit_IFU.pdf.

Accessed on December 02, 2020. 2020.

20. UK Health Security Agency. SARS-CoV-2 variants of concern and variants under investigation in England: Technical briefing 34. England2022.

21. Abu-Raddad LJ, Chemaitelly H, Butt AA, National Study Group for C-V. Effectiveness of the BNT162b2 Covid-19 Vaccine against the B.1.1.7 and B.1.351 Variants. N Engl J Med 2021;385:187-9.

22. Chemaitelly H, Yassine HM, Benslimane FM, et al. mRNA-1273 COVID-19 vaccine effectiveness against the B.1.1.7 and B.1.351 variants and severe COVID-19 disease in Qatar. Nat Med 2021;27:1614-21.

23. Abu-Raddad LJ, Chemaitelly H, Ayoub HH, et al. Association of Prior SARS-CoV-2 Infection With Risk of Breakthrough Infection Following mRNA Vaccination in Qatar. JAMA 2021;326:1930-9.

24. Abu-Raddad LJ, Chemaitelly H, Coyle P, et al. SARS-CoV-2 antibody-positivity protects against reinfection for at least seven months with $95 \%$ efficacy. EClinicalMedicine 2021;35:100861.

25. Abu-Raddad LJ, Chemaitelly H, Malek JA, et al. Assessment of the Risk of Severe Acute Respiratory Syndrome Coronavirus 2 (SARS-CoV-2) Reinfection in an Intense Reexposure Setting. Clin Infect Dis 2021;73:e1830-e40.

26. Hansen CH, Michlmayr D, Gubbels SM, Molbak K, Ethelberg S. Assessment of protection against reinfection with SARS-CoV-2 among 4 million PCR-tested individuals in Denmark in 2020: a population-level observational study. Lancet 2021;397:1204-12.

27. Kojima N, Shrestha NK, Klausner JD. A Systematic Review of the Protective Effect of Prior SARS-CoV-2 Infection on Repeat Infection. Eval Health Prof 2021;44:327-32.

28. Pilz S, Theiler-Schwetz V, Trummer C, Krause R, Ioannidis JPA. SARS-CoV-2 reinfections: Overview of efficacy and duration of natural and hybrid immunity. Environ Res 2022:112911.

29. Abu-Raddad LJ, Chemaitelly H, Bertollini R, National Study Group for Covid Epidemiology. Severity of SARS-CoV-2 Reinfections as Compared with Primary Infections. N Engl J Med 2021;385:2487-9.

30. Abu-Raddad LJ, Chemaitelly H, Ayoub HH, et al. Introduction and expansion of the SARS-CoV-2 B.1.1.7 variant and reinfections in Qatar: A nationally representative cohort study. PLoS Med 2021;18:e1003879.

31. Ayoub HH, Tomy M, Chemaitelly H, et al. Estimating protection afforded by prior infection in preventing reinfection: Applying the test-negative study design. medRxiv 2022:2022.01.02.22268622.

32. Nussenblatt V, Roder AE, Das S, et al. Year-long COVID-19 infection reveals withinhost evolution of SARS-CoV-2 in a patient with B cell depletion. medRxiv 2021.

33. Choi B, Choudhary MC, Regan J, et al. Persistence and Evolution of SARS-CoV-2 in an Immunocompromised Host. N Engl J Med 2020;383:2291-3.

34. Abu-Raddad LJ, Chemaitelly H, Malek JA, et al. Two prolonged viremic SARS-CoV-2 infections with conserved viral genome for two months. Infect Genet Evol 2021;88:104684.

35. StataCorp. Statistical Software: Release 16.1. College Station, TX: Stata Corporation 2019. 
medRxiv preprint doi: https://doi.org/10.1101/2022.03.02.22271771; this version posted March 4, 2022. The copyright holder for this preprint (which was not certified by peer review) is the author/funder, who has granted medRxiv a license to display the preprint in perpetuity.

All rights reserved. No reuse allowed without permission.

36. Ayoub HH, Chemaitelly H, Seedat S, et al. Mathematical modeling of the SARS-CoV-2 epidemic in Qatar and its impact on the national response to COVID-19. J Glob Health 2021;11:05005.

37. Coyle PV, Chemaitelly H, Ben Hadj Kacem MA, et al. SARS-CoV-2 seroprevalence in the urban population of Qatar: An analysis of antibody testing on a sample of 112,941 individuals. iScience 2021;24:102646.

38. Al-Thani MH, Farag E, Bertollini R, et al. SARS-CoV-2 Infection Is at Herd Immunity in the Majority Segment of the Population of Qatar. Open Forum Infect Dis 2021;8:ofab221.

39. Jeremijenko A, Chemaitelly $\mathrm{H}$, Ayoub HH, et al. Herd Immunity against Severe Acute Respiratory Syndrome Coronavirus 2 Infection in 10 Communities, Qatar. Emerg Infect Dis 2021;27:1343-52.

40. Lyngse FP, Kirkeby CT, Denwood M, et al. Transmission of SARS-CoV-2 Omicron VOC subvariants BA.1 and BA.2: Evidence from Danish Households. medRxiv 2022:2022.01.28.22270044.

41. Seedat S, Chemaitelly H, Ayoub HH, et al. SARS-CoV-2 infection hospitalization, severity, criticality, and fatality rates in Qatar. Sci Rep 2021;11:18182.

42. Challen R, Brooks-Pollock E, Read JM, Dyson L, Tsaneva-Atanasova K, Danon L. Risk of mortality in patients infected with SARS-CoV-2 variant of concern 202012/1: matched cohort study. BMJ 2021;372:n579. 
Figure 1. Proportion of BA.1 (versus BA.2) Omicron infections in the PCR-positive tests assessed using TaqPath COVID-19 Combo Kit during the study period.

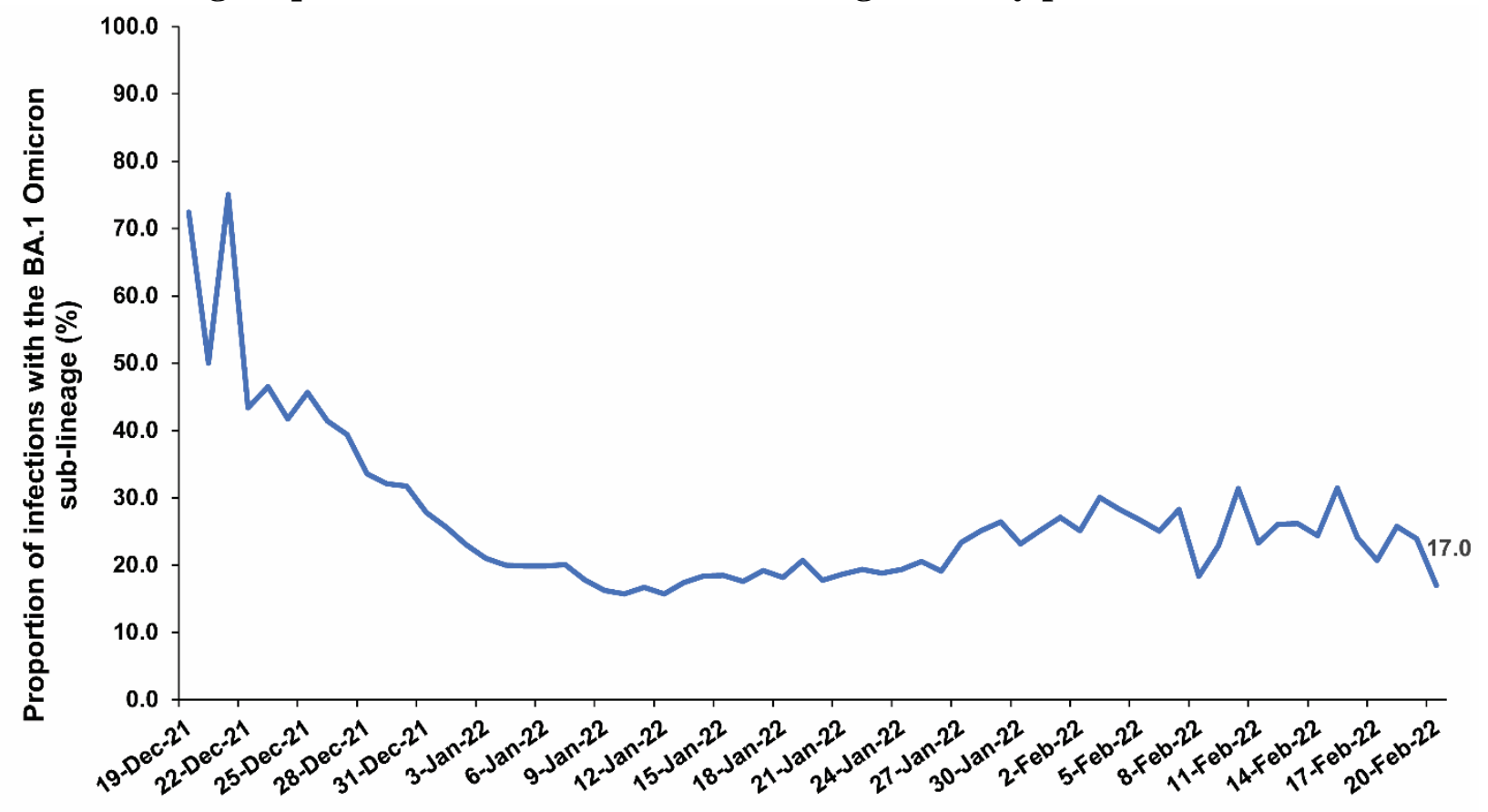


Figure 2. Flowchart describing the population selection process for investigating the infectiousness of SARS-CoV-2 Omicron variant infections.

224,448 Individuals with an RT-qPCR-confirmed SARS-CoV-2 infection between December 23, 2021 and February 20, 2022 (end of study)

\section{8,246 Excluded}

- 66,181 Were not tested using the TaqPath COVID-19 Combo Kit

- $261 \mathrm{Had}$ no available RT-qPCR cycle threshold test value

- 4 Had an RT-qPCR cycle threshold test value that appears to include a data entry error

- 1,769 Had a vaccination record with ChAdOx1 nCoV-19 (AZD1222)

- 31 Had a mixed COVID-19 vaccination regimen

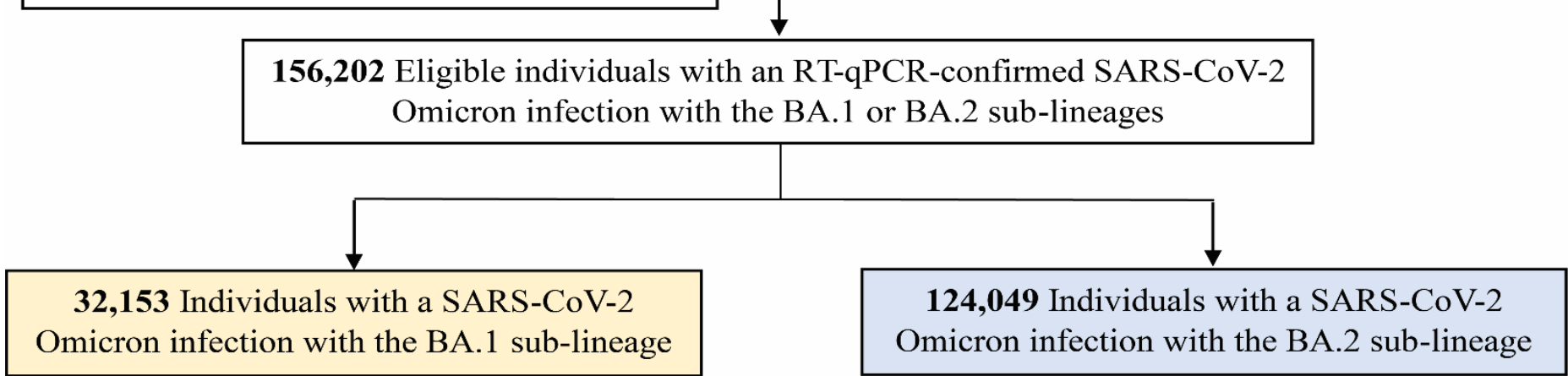

Abbreviations: COVID-19, coronavirus disease 2019; RT-qPCR, real-time reverse-transcription polymerase chain reaction; SARS-CoV-2, severe acute respiratory syndrome coronavirus 2. 
medRxiv preprint doi: https://doi.org/10.1101/2022.03.02.22271771; this version posted March 4, 2022. The copyright holder for this preprint (which was not certified by peer review) is the author/funder, who has granted medRxiv a license to display the preprint in perpetuity.

All rights reserved. No reuse allowed without permission.

Table 1. Characteristics of included individuals with SARS-CoV-2 Omicron infections between December 23, 2021 and February 20, 2022.

\begin{tabular}{|c|c|c|c|c|}
\hline Characteristics & $\begin{array}{c}\text { Overall } \\
\text { population } \\
\mathbf{N}(\%) \\
\end{array}$ & $\begin{array}{c}\text { Individuals with } \\
\text { BA.1 infection } \\
\text { N }(\%)\end{array}$ & $\begin{array}{c}\text { Individuals with } \\
\text { BA.2 infection } \\
\text { N }(\%)\end{array}$ & SMD \\
\hline Total N & 156,202 & $32,153(20.6)$ & $124,049(79.4)$ & - \\
\hline \multicolumn{5}{|l|}{ Demographic characteristics } \\
\hline Median age $($ IQR $)$ - years & $33(25-42)$ & $32(24-41)$ & $34(26-42)$ & -0.09 \\
\hline \multicolumn{5}{|l|}{ Age group in years - no. $(\%)$} \\
\hline$<10$ & $11,797(7.6)$ & $2,574(8.0)$ & $9,223(7.4)$ & \\
\hline $10-19$ & $13,881(8.9)$ & $3,566(11.1)$ & $10,315(8.3)$ & \\
\hline $20-29$ & $31,723(20.3)$ & $6,808(21.2)$ & $24,915(20.1)$ & \\
\hline $30-39$ & $50,689(32.5)$ & $9,969(31.0)$ & $40,720(32.8)$ & \\
\hline $40-49$ & $27,452(17.6)$ & $5,417(16.8)$ & $22,035(17.8)$ & 0.11 \\
\hline $50-59$ & $13,725(8.8)$ & $2,555(7.9)$ & $11,170(9.0)$ & \\
\hline $60-69$ & $5,070(3.2)$ & $962(3.0)$ & $4,108(3.3)$ & \\
\hline $70-79$ & $1,334(0.9)$ & $225(0.7)$ & $1,109(0.9)$ & \\
\hline $80+$ & $531(0.3)$ & $77(0.2)$ & $454(0.4)$ & \\
\hline \multicolumn{5}{|l|}{ Sex } \\
\hline Female & $64,375(41.2)$ & $14,585(45.4)$ & $49,790(40.1)$ & 0.11 \\
\hline Male & $91,827(58.8)$ & $17,568(54.6)$ & $74,259(59.9)$ & \\
\hline \multicolumn{5}{|l|}{ Nationality ${ }^{\dagger}$} \\
\hline Bangladeshi & $4,593(2.9)$ & $684(2.1)$ & $3,909(3.2)$ & \\
\hline Egyptian & $7,614(4.9)$ & $1,363(4.2)$ & $6,251(5.0)$ & \\
\hline Filipino & $19,241(12.3)$ & $3,600(11.2)$ & $15,641(12.6)$ & \\
\hline Indian & $32,007(20.5)$ & $5,649(17.6)$ & $26,358(21.2)$ & \\
\hline Nepalese & $7,276(4.7)$ & $1,185(3.7)$ & $6,091(4.9)$ & 0.20 \\
\hline Pakistani & $4,790(3.1)$ & $860(2.7)$ & $3,930(3.2)$ & \\
\hline Qatari & $33,633(21.5)$ & $8,218(25.6)$ & $25,415(20.5)$ & \\
\hline Sri Lankan & $4,066(2.6)$ & $629(2.0)$ & $3,437(2.8)$ & \\
\hline Sudanese & $5,064(3.2)$ & $1,007(3.1)$ & $4,057(3.3)$ & \\
\hline Other nationalities ${ }^{\ddagger}$ & $37,918(24.3)$ & $8,958(27.9)$ & $28,960(23.3)$ & \\
\hline \multicolumn{5}{|l|}{ RT-qPCR test characteristics } \\
\hline \multicolumn{5}{|l|}{ Reason for RT-qPCR testing } \\
\hline Clinical suspicion & $42,248(27.0)$ & $6,800(21.1)$ & $35,448(28.6)$ & \\
\hline Contact tracing & $21,885(14.0)$ & $3,619(11.3)$ & $18,266(14.7)$ & \\
\hline Healthcare routine testing & $2,377(1.5)$ & $432(1.3)$ & $1,945(1.6)$ & \\
\hline Survey & $16,385(10.5)$ & $3,944(12.3)$ & $12,441(10.0)$ & 0.36 \\
\hline Port of entry & $7,661(4.9)$ & $3,571(11.1)$ & $4,090(3.3)$ & \\
\hline Pre-travel & $53,747(34.4)$ & $11,530(35.9)$ & $42,217(34.0)$ & \\
\hline Individual request & $11,567(7.4)$ & $2,206(6.9)$ & $9,361(7.5)$ & \\
\hline Other & $332(0.2)$ & $51(0.2)$ & $281(0.2)$ & \\
\hline \multicolumn{5}{|l|}{ RT-qPCR test study-period week } \\
\hline Week 1 (23-29 December, 2021) & $14,963(9.6)$ & $5,419(16.9)$ & $9,544(7.7)$ & \\
\hline Week 2 (30 December, 2021-05 January, 2022) & $74,781(47.9)$ & $15,836(49.3)$ & $58,945(47.5)$ & \\
\hline Week 3 (06-12 January, 2022) & $38,392(24.6)$ & $5,927(18.4)$ & $32,465(26.2)$ & \\
\hline Week 4 (13-19 January, 2022) & $14,028(9.0)$ & $2,223(6.9)$ & $11,805(9.5)$ & 0.34 \\
\hline Week 5 (20-26 January, 2022) & $6,313(4.0)$ & $956(3.0)$ & $5,357(4.3)$ & \\
\hline Week 6 (27 January-02 February, 2022) & $3,904(2.5)$ & $891(2.8)$ & $3,013(2.4)$ & \\
\hline Week 7 (03-09 February, 2022) & $2,291(1.5)$ & $554(1.7)$ & $1,737(1.4)$ & \\
\hline Week 8 (10-16 February, 2022) & $1,145(0.7)$ & $272(0.8)$ & $873(0.7)$ & \\
\hline Week 9 (17-20 February, 2022) & $385(0.2)$ & $75(0.2)$ & $310(0.2)$ & \\
\hline \multicolumn{5}{|l|}{ Vaccine and natural immunity } \\
\hline \multicolumn{5}{|l|}{ Vaccination status } \\
\hline Unvaccinated & $45,136(28.9)$ & $9,801(30.5)$ & $35,335(28.5)$ & \\
\hline One dose & $1,082(0.7)$ & $196(0.6)$ & $886(0.7)$ & \\
\hline \multicolumn{5}{|l|}{ Two doses } \\
\hline$<3$ months before the RT-qPCR test & $2,493(1.6)$ & 604 (1.9) & $1,889(1.5)$ & \\
\hline $3-<6$ months before the RT-qPCR test & $17,348(11.1)$ & $3,259(10.1)$ & $14,089(11.4)$ & 0.08 \\
\hline 6- $<9$ months before the RT-qPCR test & $50,678(32.4)$ & $9,946(30.9)$ & $40,732(32.8)$ & \\
\hline$\geq 9$ months before the RT-qPCR test & $23,402(15.0)$ & $5,133(16.0)$ & $18,269(14.7)$ & \\
\hline
\end{tabular}


medRxiv preprint doi: https://doi.org/10.1101/2022.03.02.22271771; this version posted March 4, 2022. The copyright holder for this preprint (which was not certified by peer review) is the author/funder, who has granted medRxiv a license to display the preprint in perpetuity.

All rights reserved. No reuse allowed without permission.

Three doses

$\leq 1$ month before the RT-qPCR test

$7,890(5.1)$

$8,173(5.2)$

$>1$ month before the RT-qPCR test

\section{Previous SARS-CoV-2 infection}

\section{Never}

$<90$ days before the study RT-qPCR test ${ }^{\S}$

Prior infection"
$141,839(90.8)$

$560(0.4)$

$13,803(8.8)$

\section{1,485 (4.6)}

$1,729(5.4)$

$29,051(90.4)$

$255(0.8)$

$2,847(8.9)$
$6,405(5.2)$

$6,444(5.2)$

$112,788(90.9)$

$305(0.2)$

$10,956(8.8)$

Abbreviations: IQR, interquartile range; RT-qPCR, real-time reverse-transcription polymerase chain reaction; SARS-CoV-2, severe acute respiratory syndrome coronavirus 2; SMD, standardized mean difference.

"SMD is the difference in the mean of a covariate between groups divided by the pooled standard deviation. An SMD $<0.1$ indicates minimal differences between groups.

Nationalities were chosen to represent the most populous groups in Qatar.

†These comprise 44 other nationalities in Qatar.

${ }^{\S}$ An RT-qPCR-positive test that occurred $<90$ days before the study RT-qPCR-positive test was included separately in the analysis, but was not considered a prior

infection. This RT-qPCR-positive test and the study RT-qPCR-positive test may both reflect the same prolonged infection.

"Prior infection was defined as an RT-qPCR-positive test that occurred $\geq 90$ days before the RT-qPCR-positive test that is included in the study. 
Table 2. Associations with RT-qPCR Ct value among 156,202 individuals with SARS-CoV-2 Omicron infection between December 23, 2021 and February 20, 2022.

\begin{tabular}{|c|c|c|c|c|c|c|}
\hline \multirow[t]{2}{*}{ Characteristics } & \multirow{2}{*}{$\begin{array}{l}\text { RT-qPCR Ct value } \\
\text { Mean (SD) }\end{array}$} & \multicolumn{2}{|l|}{ Univariable analysis } & \multirow{2}{*}{$\begin{array}{l}\text { F-test } \\
\text { p-value }\end{array}$} & \multicolumn{2}{|l|}{ Multivariable analysis ${ }^{\dagger}$} \\
\hline & & $\beta$ coefficient $[95 \% \mathrm{CI}]$ & p-value & & $\beta$ coefficient $[95 \% \mathrm{CI}]$ & p-value \\
\hline Age group in years & & & & $<0.001$ & & \\
\hline $10-19$ & $24.56(6.13)$ & Ref. & & & Ref. & \\
\hline$<10$ & $27.48(5.85)$ & $2.92[2.77,3.07]$ & $<0.001$ & & $2.99[2.84,3.13]$ & $<0.001$ \\
\hline $20-29$ & $24.29(6.11)$ & $-0.26[-0.39,-0.14]$ & $<0.001$ & & $-0.03[-0.15,0.08]$ & 0.568 \\
\hline $30-39$ & $23.83(6.07)$ & $-0.73[-0.84,-0.61]$ & $<0.001$ & & $-0.30[-0.41,-0.19]$ & $<0.001$ \\
\hline $40-49$ & $23.82(6.12)$ & $-0.73[-0.86,-0.61]$ & $<0.001$ & & $-0.38[-0.50,-0.25]$ & $<0.001$ \\
\hline $50-59$ & $23.51(6.18)$ & $-1.05[-1.20,-0.91]$ & $<0.001$ & & $-0.79[-0.93,-0.65]$ & $<0.001$ \\
\hline $60-69$ & $23.52(6.19)$ & $-1.04[-1.24,-0.85]$ & $<0.001$ & & $-1.03[-1.21,-0.84]$ & $<0.001$ \\
\hline $70-79$ & $22.84(6.06)$ & $-1.72[-2.07,-1.38]$ & $<0.001$ & & $-1.67[-1.99,-1.35]$ & $<0.001$ \\
\hline $80+$ & $22.30(5.87)$ & $-2.25[-2.78,-1.73]$ & $<0.001$ & & $-2.09[-2.57,-1.61]$ & $<0.001$ \\
\hline Sex & & & & $<0.001$ & & \\
\hline Female & $24.11(6.18)$ & Ref. & & & Ref. & \\
\hline Male & $24.28(6.16)$ & $0.17[0.10,0.23]$ & $<0.001$ & & $0.24[0.18,0.30]$ & \\
\hline Nationality $^{\S}$ & & & & $<0.001$ & & \\
\hline Qatari & $24.56(6.08)$ & Ref. & & & Ref. & \\
\hline Bangladeshi & $24.27(6.48)$ & $-0.29[-0.48,-0.10]$ & 0.003 & & $0.33[0.15,0.51]$ & $<0.001$ \\
\hline Egyptian & $23.37(5.87)$ & $-1.19[-1.34,-1.04]$ & $<0.001$ & & $-0.41[-0.55,-0.27]$ & $<0.001$ \\
\hline Filipino & $22.89(5.88)$ & $-1.67[-1.78,-1.57]$ & $<0.001$ & & $-0.96[-1.07,-0.85]$ & $<0.001$ \\
\hline Indian & $24.48(6.33)$ & $-0.09[-0.18,0.01]$ & 0.072 & & $0.08[-0.01,0.18]$ & 0.083 \\
\hline Nepalese & $25.25(6.34)$ & $0.69[0.53,0.84]$ & $<0.001$ & & $1.06[0.91,1.21]$ & $<0.001$ \\
\hline Pakistani & $24.37(6.24)$ & $-0.19[-0.38,-0.00]$ & 0.044 & & $0.29[0.12,0.46]$ & 0.001 \\
\hline Sri Lankan & $24.26(6.24)$ & $-0.30[-0.50,-0.10]$ & 0.003 & & $0.18[-0.01,0.36]$ & 0.062 \\
\hline Sudanese & $24.11(5.97)$ & $-0.46[-0.64,-0.27]$ & $<0.001$ & & $0.58[0.41,0.74]$ & $<0.001$ \\
\hline Other nationalities ${ }^{\mathbb{I}}$ & $24.30(6.14)$ & $-0.27[-0.36,-0.18]$ & $<0.001$ & & $-0.07[-0.16,0.01]$ & 0.088 \\
\hline Omicron subvariant & & & & $<0.001$ & & \\
\hline BA.1 & $27.11(6.60)$ & Ref. & & & Ref. & \\
\hline BA.2 & $23.46(5.82)$ & $-3.65[-3.73,-3.58]$ & $<0.001$ & & $-3.53[-3.60,-3.46]$ & $<0.001$ \\
\hline Reason for RT-qPCR testing & & & & $<0.001$ & & \\
\hline Survey & $24.20(6.17)$ & Ref. & & & Ref. & \\
\hline Clinical suspicion & $22.00(5.52)$ & $-2.20[-2.31,-2.09]$ & $<0.001$ & & $-1.99[-2.09,-1.89]$ & $<0.001$ \\
\hline Contact tracing & $24.78(6.24)$ & $0.58[0.46,0.70]$ & $<0.001$ & & $-0.44[-0.56,-0.33]$ & $<0.001$ \\
\hline Healthcare routine testing & $23.79(6.05)$ & $-0.41[-0.67,-0.15]$ & 0.002 & & $-0.52[-0.76,-0.28]$ & $<0.001$ \\
\hline Port of entry & $26.62(6.17)$ & $2.42[2.26,2.58]$ & $<0.001$ & & $1.30[1.14,1.45]$ & $<0.001$ \\
\hline Pre-travel & $25.38(6.16)$ & $1.18[1.08,1.29]$ & $<0.001$ & & $0.67[0.57,0.77]$ & $<0.001$ \\
\hline Individual request & $24.31(5.99)$ & $0.12[-0.03,0.26]$ & 0.112 & & $-0.10[-0.23,0.04]$ & 0.149 \\
\hline Other & $23.74(5.67)$ & $-0.45[-1.11,0.20]$ & 0.171 & & $-0.87[-1.48,-0.27]$ & 0.005 \\
\hline RT-qPCR test study-period week & & & & $<0.001$ & & \\
\hline Week 1 (23-29 December, 2021) & $23.39(5.90)$ & Ref. & & & Ref. & \\
\hline Week 2 (30 December, 2021-05 January, 2022) & $23.31(5.90)$ & $-0.08[-0.18,0.03]$ & 0.142 & & $0.47[0.37,0.57]$ & $<0.001$ \\
\hline
\end{tabular}


Week 3 (06-12 January, 2022)

Week 4 (13-19 January, 2022)

Week 5 (20-26 January, 2022)

$24.17(6.02)$

$25.88(6.23)$

$27.76(6.25)$

$28.62(6.17)$

$29.29(5.99)$

Week 7 (03-09 February, 2022)

Week 8 (10-16 February, 2022)

$28.48(6.13)$

$28.10(6.31)$

$25.38(6.27)$
$23.92(6.05)$

Vaccination status

Unvaccinated

Two doses

$<3$ months before the RT-qPCR test

$24.69(6.25)$

$24.07(6.16)$

$23.43(5.96)$

$23.47(5.97)$

6- $<9$ months before the RT-qPCR test

$24.98(6.30)$

$\leq 1$ month before the RT-qPCR test

$24.21(6.23)$

Prous SARS-CoV-2 infection

\section{Never}

$<90$ days before the study RT-qPCR test**

24.09 (6.16)

$29.18(5.41)$

$25.22(6.07)$

\section{$0.78[0.67,0.90$ \\ $2.49[2.35,2.62]$ \\ $4.37[4.20,4.55$ \\ $5.23[5.02,5.44]$ \\ $5.90[5.64,6.16$ \\ $5.09[4.73,5.45]$ \\ $4.71[4.10,5.31]$}

Ref.

-1.46 [-1.82, -1.09]

$-0.69[-0.93,-0.44]$

$-1.31[-1.42,-1.20]$

$-1.95[-2.02,-1.87]$

$-1.91[-2.00,-1.81]$

$-0.39[-0.54,-0.25]$

$-1.17[-1.31,-1.02]$

Ref.

$5.09[4.58,5.60]$

$1.12[1.01,1.23]$

deviation

The two-tailed F-test of the univariable analysis.

RT-qPCR Ct value was adjusted for age-group, sex, nationality, Omicron subvariant, reason for RT-qPCR test, RT-qPCR test study-period week, vaccination status, and prior SARS-CoV-2 infection

The 10-19 age group was chosen as a reference, and not the <10-age group, because of the different manifestations of this infection in small children.

Nationalities were chosen to represent the most populous groups on Qatar.

These comprise 44 other nationalities in Qatar

*An RT-qPCR-positive test that occurred <90 days before the study RT-qPCR-positive test was included separately in the analysis, but was not considered a prior infection. This RT-qPCR-positive test and the study RT-qPCR-

positive test may both reflect the same prolonged infection.

"Prior infection was defined as an RT-qPCR-positive test that occurred $\geq 90$ days before the RT-qPCR-positive test that is included in the study.
$<0.00$

$<0.001$

$<0.001$

0.001

$<0.001$

$<0.001$

$<0.001$

$<0.001$

Ref.

$-0.34[-0.67,-0.00]$

0.050

$0.23[0.00,0.46]$

$-0.05[-0.15,0.06]$

$-0.48[-0.56,-0.40]$

0.048

$<0.001$

$<0.00$

$-0.43[-0.53,-0.33]$

0.389

$<0.001$

$<0.001$

$<0.001$

$<0.001$

$0.86[0.72,1.00]$

$<0.001$

$<0.001$

Ref.

$4.23[3.77,4.69]$

$<.001$

$<0.001$ $<0.001$

$\begin{array}{ll}<0.001 & 1.43[1.32,1.54] \\ <0.001 & 2.92[2.79,3.05] \\ <0.001 & 4.70[4.53,4.87] \\ <0.001 & 5.10[4.90,5.30] \\ <0.001 & 5.58[5.34,5.83] \\ <0.001 & 4.73[4.39,5.06] \\ <0.001 & 4.59[4.02,5.15]\end{array}$


Table 3. Associations with RT-qPCR Ct value among 32,153 individuals with SARS-CoV-2 Omicron BA.1 subvariant infection.

\begin{tabular}{|c|c|c|c|c|c|c|}
\hline \multirow[t]{2}{*}{ Characteristics } & \multirow{2}{*}{$\begin{array}{l}\text { RT-qPCR Ct value } \\
\text { Mean (SD) } \\
\end{array}$} & \multicolumn{2}{|l|}{ Univariable analysis } & \multirow{2}{*}{$\begin{array}{l}\text { F-test }{ }^{*} \\
\text { p-value }\end{array}$} & \multicolumn{2}{|l|}{ Multivariable analysis $^{\dagger}$} \\
\hline & & $\beta$ coefficient $[95 \% \mathrm{CI}]$ & p-value & & $\beta$ coefficient $[95 \% \mathrm{CI}]$ & p-value \\
\hline Age group in years & & & & $<0.001$ & & \\
\hline $10-19$ & $26.96(6.40)$ & Ref. & & & Ref. & \\
\hline$<10$ & $30.17(5.51)$ & $3.21[2.88,3.54]$ & $<0.001$ & & $3.09[2.77,3.42]$ & $<0.001$ \\
\hline $20-29$ & $27.20(6.52)$ & $0.24[-0.03,0.50]$ & 0.082 & & $0.09[-0.16,0.35]$ & 0.469 \\
\hline $30-39$ & $26.76(6.69)$ & $-0.20[-0.45,0.05]$ & 0.113 & & $-0.23[-0.48,0.02]$ & 0.069 \\
\hline $40-49$ & $26.69(6.66)$ & $-0.27[-0.55,0.01]$ & 0.055 & & $-0.37[-0.64,-0.10]$ & 0.008 \\
\hline $50-59$ & $26.69(6.76)$ & $-0.27[-0.61,0.06]$ & 0.105 & & $-0.56[-0.89,-0.24]$ & 0.001 \\
\hline $60-69$ & $26.59(6.68)$ & $-0.37[-0.83,0.10]$ & 0.123 & & $-0.93[-1.37,-0.49]$ & $<0.001$ \\
\hline $70-79$ & $25.69(6.95)$ & $-1.27[-2.15,-0.39]$ & 0.005 & & $-1.74[-2.56,-0.92]$ & $<0.001$ \\
\hline $80+$ & $25.14(7.10)$ & $-1.82[-3.30,-0.35]$ & 0.015 & & $-2.41[-3.77,-1.04]$ & 0.001 \\
\hline Sex & & & & $<0.001$ & & \\
\hline Female & $26.67(6.57)$ & Ref. & & & Ref. & \\
\hline Male & $27.48(6.60)$ & $0.81[0.67,0.96]$ & $<0.001$ & & $0.31[0.16,0.45]$ & $<0.001$ \\
\hline Nationality ${ }^{\S}$ & & & & $<0.001$ & & \\
\hline Qatari & $26.89(6.34)$ & Ref. & & & Ref. & \\
\hline Bangladeshi & $28.95(6.87)$ & $2.06[1.55,2.57]$ & $<0.001$ & & $1.49[1.01,1.98]$ & $<0.001$ \\
\hline Egyptian & $26.22(6.45)$ & $-0.66[-1.04,-0.29]$ & 0.001 & & $-0.49[-0.84,-0.14]$ & 0.006 \\
\hline Filipino & $25.21(6.69)$ & $-1.67[-1.93,-1.42]$ & $<0.001$ & & $-1.22[-1.47,-0.96]$ & $<0.001$ \\
\hline Indian & $28.08(6.76)$ & $1.20[0.98,1.42]$ & $<0.001$ & & $0.47[0.24,0.69]$ & $<0.001$ \\
\hline Nepalese & $29.42(6.55)$ & $2.54[2.14,2.93]$ & $<0.001$ & & $1.88[1.49,2.26]$ & $<0.001$ \\
\hline Pakistani & $27.60(6.54)$ & $0.72[0.26,1.18]$ & 0.002 & & $0.00[-0.43,0.43]$ & 0.999 \\
\hline Sri Lankan & $28.38(6.76)$ & $1.49[0.96,2.02]$ & $<0.001$ & & $0.92[0.42,1.42]$ & $<0.001$ \\
\hline Sudanese & $26.85(6.47)$ & $-0.03[-0.46,0.40]$ & 0.890 & & $0.38[-0.02,0.78]$ & 0.065 \\
\hline Other nationalities $\mathrm{S}^{\mathbb{I}}$ & $27.05(6.47)$ & $0.17[-0.03,0.36]$ & 0.092 & & $-0.07[-0.26,0.12]$ & 0.466 \\
\hline Reason for RT-qPCR testing & & & & $<0.001$ & & \\
\hline Survey & $26.69(6.53)$ & Ref. & & & Ref. & \\
\hline Clinical suspicion & $24.43(6.43)$ & $-2.26[-2.51,-2.01]$ & $<0.001$ & & $-2.20[-2.44,-1.96]$ & $<0.001$ \\
\hline Contact tracing & $28.10(6.78)$ & $1.42[1.13,1.71]$ & $<0.001$ & & $-0.03[-0.30,0.25]$ & 0.854 \\
\hline Healthcare routine testing & $27.28(6.53)$ & $0.59[-0.05,1.23]$ & 0.069 & & $0.02[-0.58,0.62]$ & 0.943 \\
\hline Port of entry & $27.65(6.09)$ & $0.96[0.67,1.25]$ & $<0.001$ & & $0.52[0.24,0.79]$ & $<0.001$ \\
\hline Pre-travel & $28.31(6.37)$ & $1.63[1.39,1.86]$ & $<0.001$ & & $0.61[0.38,0.83]$ & $<0.001$ \\
\hline Individual request & $27.37(6.50)$ & $0.68[0.34,1.01]$ & $<0.001$ & & $0.09[-0.22,0.41]$ & 0.569 \\
\hline Other & $25.86(6.93)$ & $-0.83[-2.61,0.95]$ & 0.360 & & $-1.32[-2.98,0.35]$ & 0.121 \\
\hline RT-qPCR test study-period week & & & & $<0.001$ & & \\
\hline Week 1 (23-29 December, 2021) & $25.81(6.39)$ & Ref. & & & Ref. & \\
\hline Week 2 (30 December, 2021-05 January, 2022) & $25.96(6.40)$ & $0.14[-0.05,0.34]$ & 0.148 & & $0.17[-0.02,0.35]$ & 0.083 \\
\hline Week 3 (06-12 January, 2022) & $27.76(6.50)$ & $1.94[1.71,2.18]$ & $<0.001$ & & $1.69[1.46,1.91]$ & $<0.001$ \\
\hline Week 4 (13-19 January, 2022) & $30.32(5.99)$ & $4.50[4.19,4.81]$ & $<0.001$ & & $3.97[3.66,4.27]$ & $<0.001$ \\
\hline Week 5 (20-26 January, 2022) & $32.08(5.36)$ & $6.27[5.84,6.70]$ & $<0.001$ & & $5.65[5.23,6.07]$ & $<0.001$ \\
\hline
\end{tabular}


Week 6 (27 January-02 February, 2022)

Week 7 (03-09 February, 2022)

Week 8 (10-16 February, 2022)

Week 9 (17-20 February, 2022)

Vaccination status

Unvaccinated

One dose

Two doses

$<3$ months before the RT-qPCR test

$3-<6$ months before the RT-qPCR test

6- $<9$ months before the RT-qPCR test

$\geq 9$ months before the RT-qPCR test

Three doses

$\leq 1$ month before the RT-qPCR test

$>1$ month before the RT-qPCR test

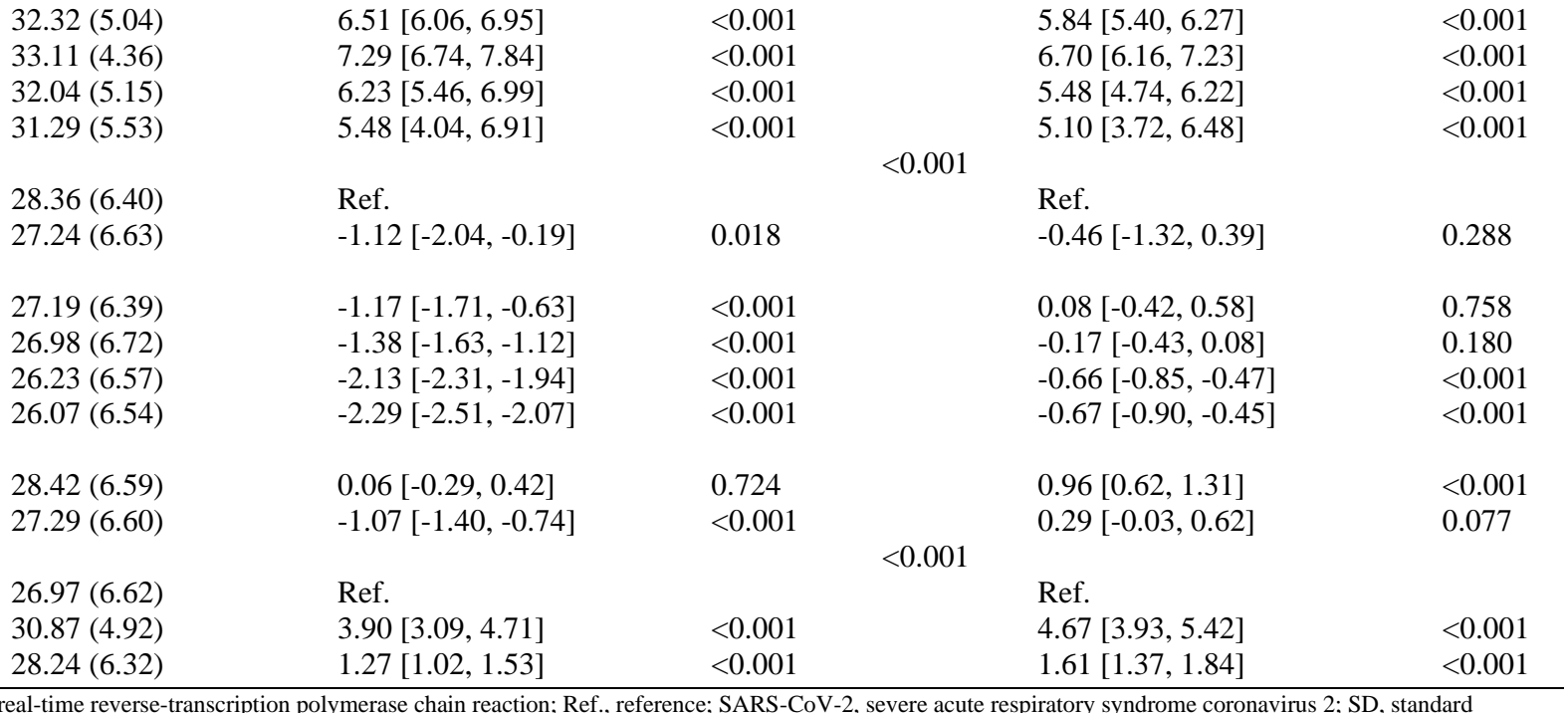

Previous SARS-CoV-2 infection

Never

$<90$ days before the study RT-qPCR test*

$1.27[1.02,1.53]$

$<0.00$

$1.61[1.37,1.84$

$<0.001$

Abbreviations: CI, confidence interval; Ct, cycle threshold; RT-qPCR, real-time reverse-transcription polymerase chain reaction; Ref., reference; SARS-CoV-2, severe acute respiratory syndrome coronavirus 2; SD, standard

deviation

The two-tailed F-test of the univariable analysis.

RT-qPCR Ct value was adjusted for age-group, sex, nationality, Omicron subvariant, reason for RT-qPCR test, RT-qPCR test study-period week, vaccination status, and prior SARS-CoV-2 infection.

The 10-19 age group was chosen as a reference, and not the <10-age group, because of the different manifestations of this infection in small children.

Nationalities were chosen to represent the most populous groups on Qatar.

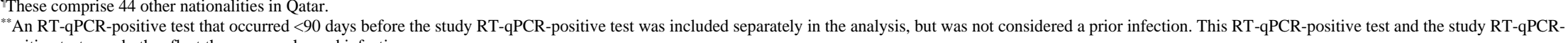

positive test may both reflect the same prolonged infection.

"Prior infection was defined as an RT-qPCR-positive test that occurred $\geq 90$ days before the RT-qPCR-positive test that is included in the study. 
Table 4. Associations with RT-qPCR Ct value among 124,049 individuals with SARS-CoV-2 Omicron BA.2 subvariant infection.

\begin{tabular}{|c|c|c|c|c|c|c|}
\hline \multirow[t]{2}{*}{ Characteristics } & \multirow{2}{*}{$\begin{array}{l}\text { RT-qPCR Ct value } \\
\text { Mean (SD) } \\
\end{array}$} & \multicolumn{2}{|l|}{ Univariable analysis } & \multirow{2}{*}{$\begin{array}{l}\text { F-test* } \\
\text { p-value }\end{array}$} & \multicolumn{2}{|l|}{ Multivariable analysis $^{\dagger}$} \\
\hline & & $\beta$ coefficient $[95 \% \mathrm{CI}]$ & p-value & & $\beta$ coefficient $[95 \% \mathrm{CI}]$ & p-value \\
\hline Age group in years & & & & $<0.001$ & & \\
\hline $10-19$ & $23.73(5.81)$ & Ref. & & & Ref. & \\
\hline$<10$ & $26.73(5.72)$ & $3.00[2.84,3.16]$ & $<0.001$ & & $2.95[2.80,3.11]$ & $<0.001$ \\
\hline $20-29$ & $23.50(5.74)$ & $-0.23[-0.36,-0.10]$ & 0.001 & & $-0.09[-0.22,0.04]$ & 0.160 \\
\hline $30-39$ & $23.12(5.68)$ & $-0.61[-0.74,-0.49]$ & $<0.001$ & & $-0.34[-0.47,-0.22]$ & $<0.001$ \\
\hline $40-49$ & $23.12(5.77)$ & $-0.61[-0.74,-0.47]$ & $<0.001$ & & $-0.40[-0.54,-0.27]$ & $<0.001$ \\
\hline $50-59$ & $22.78(5.80)$ & $-0.95[-1.11,-0.80]$ & $<0.001$ & & $-0.85[-1.01,-0.70]$ & $<0.001$ \\
\hline $60-69$ & $22.79(5.84)$ & $-0.93[-1.14,-0.73]$ & $<0.001$ & & $-1.07[-1.27,-0.87]$ & $<0.001$ \\
\hline $70-79$ & $22.26(5.70)$ & $-1.47[-1.83,-1.12]$ & $<0.001$ & & $-1.68[-2.02,-1.34]$ & $<0.001$ \\
\hline $80+$ & $21.82(5.51)$ & $-1.90[-2.44,-1.37]$ & $<0.001$ & & $-2.06[-2.57,-1.55]$ & $<0.001$ \\
\hline Sex & & & & $<0.001$ & & \\
\hline Female & $23.37(5.85)$ & Ref. & & & Ref. & \\
\hline Male & $23.52(5.80)$ & $0.16[0.09,0.22]$ & $<0.001$ & & $0.20[0.13,0.26]$ & $<0.001$ \\
\hline Nationality ${ }^{\S}$ & & & & $<0.001$ & & \\
\hline Qatari & $23.81(5.80)$ & Ref. & & & Ref. & \\
\hline Bangladeshi & $23.46(6.04)$ & $-0.36[-0.55,-0.16]$ & $<0.001$ & & $0.06[-0.13,0.25]$ & 0.512 \\
\hline Egyptian & $22.75(5.54)$ & $-1.06[-1.22,-0.90]$ & $<0.001$ & & $-0.45[-0.60,-0.29]$ & $<0.001$ \\
\hline Filipino & $22.35(5.54)$ & $-1.46[-1.57,-1.34]$ & $<0.001$ & & $-0.96[-1.08,-0.85]$ & $<0.001$ \\
\hline Indian & $23.70(5.96)$ & $-0.11[-0.21,-0.01]$ & 0.033 & & $-0.08[-0.18,0.03]$ & 0.150 \\
\hline Nepalese & $24.44(5.97)$ & $0.63[0.47,0.79]$ & $<0.001$ & & $0.81[0.65,0.97]$ & $<0.001$ \\
\hline Pakistani & $23.67(5.95)$ & $-0.15[-0.34,0.05]$ & 0.139 & & $0.29[0.11,0.48]$ & 0.002 \\
\hline Sri Lankan & $23.51(5.83)$ & $-0.30[-0.51,-0.10]$ & 0.004 & & $-0.03[-0.23,0.16]$ & 0.731 \\
\hline Sudanese & $23.43(5.64)$ & $-0.39[-0.58,-0.20]$ & $<0.001$ & & $0.57[0.39,0.75]$ & $<0.001$ \\
\hline Other nationalities ${ }^{\mathbb{I}}$ & $23.44(5.77)$ & $-0.37[-0.47,-0.27]$ & $<0.001$ & & $-0.12[-0.21,-0.02]$ & 0.015 \\
\hline Reason for RT-qPCR testing & & & & $<0.001$ & & \\
\hline Survey & $23.41(5.84)$ & Ref. & & & Ref. & \\
\hline Clinical suspicion & $21.53(5.20)$ & $-1.88[-2.00,-1.76]$ & $<0.001$ & & $-1.95[-2.06,-1.84]$ & $<0.001$ \\
\hline Contact tracing & $24.12(5.91)$ & $0.71[0.58,0.84]$ & $<0.001$ & & $-0.50[-0.63,-0.38]$ & $<0.001$ \\
\hline Healthcare routine testing & $23.01(5.66)$ & $-0.40[-0.67,-0.13]$ & 0.004 & & $-0.63[-0.89,-0.37]$ & $<0.001$ \\
\hline Port of entry & $25.72(6.09)$ & $2.31[2.11,2.51]$ & $<0.001$ & & $1.96[1.77,2.15]$ & $<0.001$ \\
\hline Pre-travel & $24.58(5.86)$ & $1.17[1.06,1.29]$ & $<0.001$ & & $0.68[0.57,0.79]$ & $<0.001$ \\
\hline Individual request & $23.60(5.63)$ & $0.19[0.03,0.34]$ & 0.017 & & $-0.15[-0.29,-0.00]$ & 0.048 \\
\hline Other & $23.36(5.34)$ & $-0.05[-0.72,0.62]$ & 0.886 & & $-0.80[-1.44,-0.16]$ & 0.014 \\
\hline RT-qPCR test study-period week & & & & $<0.001$ & & \\
\hline Week 1 (23-29 December, 2021) & $22.02(5.11)$ & Ref. & & & Ref. & \\
\hline Week 2 (30 December, 2021-05 January, 2022) & $22.60(5.55)$ & $0.59[0.46,0.71]$ & $<0.001$ & & $0.51[0.39,0.62]$ & $<0.001$ \\
\hline Week 3 (06-12 January, 2022) & $23.52(5.69)$ & $1.50[1.38,1.63]$ & $<0.001$ & & $1.32[1.19,1.45]$ & $<0.001$ \\
\hline Week 4 (13-19 January, 2022) & $25.04(5.91)$ & $3.03[2.87,3.18]$ & $<0.001$ & & $2.64[2.49,2.79]$ & $<0.001$ \\
\hline
\end{tabular}


Week 5 (20-26 January, 2022)

Week 6 (27 January-02 February, 2022)

$26.99(6.09)$

$27.53(6.04)$

Week 7 (03-09 February, 2022)

$28.07(5.93)$

$5.51[5.28,5.74]$

$27.37(5.98)$

$5.36[4.97,5.75]$

$27.33(6.25)$

$5.31[4.67,5.95]$

$24.55(5.97)$

Ref.

Unvaccinated

$23.18(5.66)$

$-1.36[-1.75,-0.98]$

23.89 (5.99)

$23.39(5.82)$

$-0.66[-0.93,-0.39]$

$<3$ months before the RT-qPCR test

$3-<6$ months before the RT-qPCR test

$22.75(5.59)$

$-1.16[-1.27,-1.04]$

$-1.80[-1.88,-1.72]$

$22.74(5.59)$

$-1.81[-1.91,-1.71]$

$4.45[4.27,4.64]$

$<0.001$

$6-<9$ months before the RT-qPCR test

$24.19(5.96)$

$-0.36[-0.52,-0.21]$

$\leq 1$ month before the RT-qPCR test

$23.38(5.86)$

$-1.17[-1.32,-1.01]$

$4.78[4.56,5.01]$

$5.15[4.87,5.43]$

$<0.001$

$<0.001$

$4.41[4.03,4.79]$

$<0.00$

$4.40[3.78,5.01]$

$<0.001$

Ref.

$-0.32[-0.68,0.04]$

0.083

$<0.001$

$<0.001$

$<0.001$

$0.31[0.05,0.56]$

0.017

$0.01[-0.10,0.12]$

$-0.42[-0.51,-0.33]<0.001$

$-0.34[-0.45,-0.24] \quad<0.001$

$>1$ month before the RT-qPCR test

$23.35(5.82)$

$27.78(5.40)$

Ref

$<0.001$

$0.84[0.69,0.99] \quad<0.001$

Never

$<90$ days before the study RT-qPCR test ${ }^{* *}$

$24.43(5.75)$

$4.42[3.77,5.07]$

$1.08[0.96,1.19]$

$<0.001$

$<0.001$

Ref.

$3.95[3.34,4.56] \quad<0.001$ $1.23[1.12,1.33]$

$<0.001$ $<0.001$

Abbreviations: CI, confidence interval; Ct, cycle threshold; RT-qPCR, real-time reverse-transcription polymerase chain reaction; Ref., reference; SARS-CoV-2, severe acute respiratory syndrome coronavirus 2; SD, standard

deviation

The two-tailed F-test of the univariable analysis.

RT-qPCR Ct value was adjusted for age-group, sex, nationality, Omicron subvariant, reason for RT-qPCR test, RT-qPCR test study-period week, vaccination status, and prior SARS-CoV-2 infection

"The 10-19 age group was chosen as a reference, and not the <10-age group, because of the different manifestations of this infection in small children.

${ }^{8}$ Nationalities were chosen to represent the most populous groups on Qatar.

"These comprise 44 oher nationalities in Qatar.

"An RT-qPCR-positive test that occurred <90 days before the study RT-qPCR-positive test was included separately in the analysis, but was not considered a prior infection. This RT-qPCR-positive test and the study RT-qPCR-

positive test may both reflect the same prolonged infection.

"Prior infection was defined as an RT-qPCR-positive test that occurred $\geq 90$ days before the RT-qPCR-positive test that is included in the study 
medRxiv preprint doi: https://doi.org/10.1101/2022.03.02.22271771; this version posted March 4, 2022. The copyright holder for this preprint (which was not certified by peer review) is the author/funder, who has granted medRxiv a license to display the preprint in perpetuity.

All rights reserved. No reuse allowed without permission.

\section{Supplementary Appendix}

\section{Table of contents}

Section S1. Laboratory methods and variant ascertainment ........................................................ 2

Real-time reverse-transcription polymerase chain reaction testing ......................................... 2

Classification of infections by variant type .........................................................................

Table S1. STROBE checklist for cross-sectional studies. ............................................................ 5

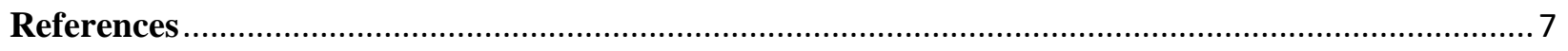


medRxiv preprint doi: https://doi.org/10.1101/2022.03.02.22271771; this version posted March 4, 2022. The copyright holder for this preprint (which was not certified by peer review) is the author/funder, who has granted medRxiv a license to display the preprint in perpetuity.

All rights reserved. No reuse allowed without permission.

\section{Section S1. Laboratory methods and variant ascertainment}

\section{Real-time reverse-transcription polymerase chain reaction testing}

Nasopharyngeal and/or oropharyngeal swabs were collected for polymerase chain reaction (PCR) testing and placed in Universal Transport Medium (UTM). Aliquots of UTM were: 1) extracted on KingFisher Flex (Thermo Fisher Scientific, USA), MGISP-960 (MGI, China), or ExiPrep 96 Lite (Bioneer, South Korea) followed by testing with real-time reverse-transcription PCR (RT-qPCR) using TaqPath COVID-19 Combo Kits (Thermo Fisher Scientific, USA) on an ABI 7500 FAST (Thermo Fisher Scientific, USA); 2) tested directly on the Cepheid GeneXpert system using the Xpert Xpress SARS-CoV-2 (Cepheid, USA); or 3) loaded directly into a Roche cobas 6800 system and assayed with the cobas SARS-CoV-2 Test (Roche, Switzerland). The first assay targets the viral S, N, and ORF1ab gene regions. The second targets the viral N and Egene regions, and the third targets the ORF1ab and E-gene regions.

All PCR testing was conducted at the Hamad Medical Corporation Central Laboratory or Sidra Medicine Laboratory, following standardized protocols.

\section{Classification of infections by variant type}

Surveillance for severe acute respiratory syndrome coronavirus 2 (SARS-CoV-2) variants in Qatar is mainly based on viral genome sequencing and multiplex RT-qPCR variant screening ${ }^{1}$ of random positive clinical samples,${ }^{2-7}$ complemented by deep sequencing of wastewater samples. ${ }^{4,8}$ A total of 315 random SARS-CoV-2-positive specimens collected between December 19, 2021 and January 22, 2022 were viral whole-genome sequenced on a Nanopore GridION sequencing device. Of these, $300(95.2 \%)$ were confirmed as Omicron (B.1.1.529) ${ }^{9}$ infections and $15(4.8 \%)$ as Delta (B.1.617.2) $)^{9}$ infections. ${ }^{4,10,11}$ Of 286 Omicron infections with confirmed subvariant 
medRxiv preprint doi: https://doi.org/10.1101/2022.03.02.22271771; this version posted March 4, 2022. The copyright holder for this preprint (which was not certified by peer review) is the author/funder, who has granted medRxiv a license to display the preprint in perpetuity.

All rights reserved. No reuse allowed without permission.

status, $68(23.8 \%)$ were BA.1 cases and $218(76.2 \%)$ were BA.2 cases. No Delta case was detected in sequencing after January 8, 2022, nor were other variants.

Additionally, a total of 1,315 random SARS-CoV-2-positive specimens collected between December 22, 2021 and January 1, 2022 were RT-qPCR genotyped. The RT-qPCR genotyping identified 1 B.1.617.2-like Delta case, 366 BA.1-like Omicron cases, 898 BA.2-like Omicron cases, and 50 were undetermined cases where the genotype could not be assigned.

The accuracy of the RT-qPCR genotyping was verified against either Sanger sequencing of the receptor-binding domain $(\mathrm{RBD})$ of SARS-CoV-2 surface glycoprotein $(\mathrm{S})$ gene, or by viral whole-genome sequencing on a Nanopore GridION sequencing device. From 147 random SARS-CoV-2-positive specimens all collected in December of 2021, RT-qPCR genotyping was able to assign a genotype in 129 samples. The agreement between RT-qPCR genotyping and sequencing was $100 \%$ for Delta $(n=82), 100 \%$ for Omicron BA.1 $(n=18)$, and $93 \%$ for Omicron BA.2 (27 of 29 were correctly assigned to BA.2 and remaining 2 specimens genotyped as BA.2 were B.1.617.2 by sequencing). Of the remaining 18 specimens: 10 failed PCR amplification and sequencing, 8 could not be assigned a genotype by RT-qPCR ( 4 of 8 were B.1.617.2 by sequencing, and the remaining 4 failed sequencing). All the variant RT-qPCR genotyping was conducted at the Sidra Medicine Laboratory following standardized protocols.

The large Omicron-wave exponential-growth phase in Qatar started on December 19, 2021 and peaked in mid-January, 2022.,10-13 The study duration coincided with the intense Omicron wave where Delta incidence was limited. Accordingly, any PCR-positive test during the study duration, between December 23, 2021 and February 20, 2022, was assumed to be an Omicron infection. Of note that the study duration started on December 23, 2021, and not on December 
medRxiv preprint doi: https://doi.org/10.1101/2022.03.02.22271771; this version posted March 4, 2022. The copyright holder for this preprint

(which was not certified by peer review) is the author/funder, who has granted medRxiv a license to display the preprint in perpetuity.

All rights reserved. No reuse allowed without permission.

19, 2021, to minimize the occurrence of residual Delta incidence during the first few days of the Omicron wave.

Informed by the viral genome sequencing and the RT-qPCR genotyping, a SARS-CoV-2

infection with the BA.1 subvariant was proxied as an S-gene "target failure" (SGTF) case using the TaqPath COVID-19 Combo Kit (Thermo Fisher Scientific, USA ${ }^{14}$ ) that tests for the S-gene and is affected by the del69/70 mutation in the S-gene. ${ }^{15}$ A SARS-CoV-2 infection with the BA.2 subvariant was proxied as a non-SGTF case using this TaqPath Kit. For ascertainment of subvariant status and standardization of RT-qPCR cycle threshold values, we analyzed only the RT-qPCR-confirmed infections diagnosed with this TaqPath Kit. 
Table S1. STROBE checklist for cross-sectional studies.

Item No Recommendations

\begin{tabular}{|c|c|c|c|}
\hline \multirow[t]{2}{*}{ Title and abstract } & \multirow[t]{2}{*}{1} & $\begin{array}{l}\text { (a) Indicate the study's design with a commonly used } \\
\text { term in the title or the abstract }\end{array}$ & $\begin{array}{l}\text { Methods ('Study population, data } \\
\text { sources, and study design', } \\
\text { paragraph 1) } \\
\end{array}$ \\
\hline & & $\begin{array}{l}\text { (b) Provide in the abstract an informative and balanced } \\
\text { summary of what was done and what was found }\end{array}$ & Abstract \\
\hline \multicolumn{4}{|l|}{ Introduction } \\
\hline Background/rationale & 2 & $\begin{array}{l}\text { Explain the scientific background and rationale for the } \\
\text { investigation being reported }\end{array}$ & Introduction \\
\hline Objectives & 3 & $\begin{array}{l}\text { State specific objectives, including any prespecified } \\
\text { hypotheses }\end{array}$ & $\begin{array}{l}\text { Methods ('Study population, data } \\
\text { sources, and study design') }\end{array}$ \\
\hline \multicolumn{4}{|l|}{ Methods } \\
\hline Study design & 4 & Present key elements of study design early in the paper & $\begin{array}{l}\text { Methods ('Study population, data } \\
\text { sources, and study design') }\end{array}$ \\
\hline Setting & 5 & $\begin{array}{l}\text { Describe the setting, locations, and relevant dates, } \\
\text { including periods of recruitment, exposure, follow-up, } \\
\text { and data collection }\end{array}$ & $\begin{array}{l}\text { Methods ('Study population, data } \\
\text { sources, and study design') and } \\
\text { Section S1 ('Classification of } \\
\text { infections by variant type') of } \\
\text { Supplementary Appendix }\end{array}$ \\
\hline Participants & 6 & $\begin{array}{l}\text { (a) Give the eligibility criteria, and the sources and } \\
\text { methods of selection of participants }\end{array}$ & $\begin{array}{l}\text { Methods ('Study population, data } \\
\text { sources, and study design') \& } \\
\text { Figure } 2 \\
\end{array}$ \\
\hline Variables & 7 & $\begin{array}{l}\text { Clearly define all outcomes, exposures, predictors, } \\
\text { potential confounders, and effect modifiers. Give } \\
\text { diagnostic criteria, if applicable }\end{array}$ & $\begin{array}{l}\text { Methods ('Study population, data } \\
\text { sources, and study design' \& } \\
\text { 'Statistical analysis') \& Section S1 } \\
\text { ('Classification of infections by } \\
\text { variant type') of Supplementary } \\
\text { Appendix } \\
\end{array}$ \\
\hline $\begin{array}{l}\text { Data sources/ } \\
\text { measurement }\end{array}$ & 8 & $\begin{array}{l}\text { For each variable of interest, give sources of data and } \\
\text { details of methods of assessment (measurement). } \\
\text { Describe comparability of assessment methods if there is } \\
\text { more than one group }\end{array}$ & $\begin{array}{c}\text { Methods ('Study population, data } \\
\text { sources, and study design'), Table } \\
1, \& \text { Section S1 of Supplementary } \\
\text { Appendix } \\
\end{array}$ \\
\hline Bias & 9 & Describe any efforts to address potential sources of bias & $\begin{array}{l}\text { Methods ('Study population, data } \\
\text { sources, and study design' \& } \\
\text { 'Statistical analysis') }\end{array}$ \\
\hline Study size & 10 & Explain how the study size was arrived at & $\begin{array}{l}\text { Methods ('Study population, data } \\
\text { sources, and study design’) \& } \\
\text { Figure } 2\end{array}$ \\
\hline $\begin{array}{l}\text { Quantitative } \\
\text { variables }\end{array}$ & 11 & $\begin{array}{l}\text { Explain how quantitative variables were handled in the } \\
\text { analyses. If applicable, describe which groupings were } \\
\text { chosen and why }\end{array}$ & $\begin{array}{l}\text { Methods ('Study population, data } \\
\text { sources, and study design' \& } \\
\text { 'Statistical analysis'), \& Tables 1-4 }\end{array}$ \\
\hline \multirow{5}{*}{ Statistical methods } & \multirow{5}{*}{12} & $\begin{array}{l}\text { (a) Describe all statistical methods, including those used } \\
\text { to control for confounding }\end{array}$ & Methods ('Statistical analysis') \\
\hline & & $\begin{array}{l}\text { (b) Describe any methods used to examine subgroups } \\
\text { and interactions }\end{array}$ & $\begin{array}{c}\text { Methods ('Study population, data } \\
\text { sources, and study design' \& } \\
\text { 'Statistical analysis'), \& Tables 1, } 3 \\
\& 4\end{array}$ \\
\hline & & (c) Explain how missing data were addressed & $\begin{array}{c}\text { Methods ('Study population, data } \\
\text { sources, and study design') \& } \\
\text { Figure } 2 \\
\end{array}$ \\
\hline & & $\begin{array}{l}\text { (d) If applicable, describe analytical methods taking } \\
\text { account of sampling strategy }\end{array}$ & NA \\
\hline & & $(\underline{e})$ Describe any sensitivity analyses & NA \\
\hline
\end{tabular}

Results

Participants

13

Descriptive data

14 (a) Report numbers of individuals at each stage of study - eg numbers potentially eligible, examined for eligibility, confirmed eligible, included in the study, completing follow-up, and analysed Figure 2

(b) Give reasons for non-participation at each stage (c) Consider use of a flow diagram

(a) Give characteristics of study participants (eg demographic, clinical, social) and information on exposures and potential confounders
Main text page No thods ('Study population, da paragraph 1)

Abstract 
(b) Indicate number of participants with missing data for each variable of interest
Methods ('Study population, data sources, and study design') \& Figure 2

\begin{tabular}{|c|c|c|c|}
\hline & & & \\
\hline Outcome data & 15 & $\begin{array}{l}\text { Report numbers of outcome events or summary } \\
\text { measures }\end{array}$ & Results \& Table 1 \\
\hline \multirow[t]{3}{*}{ Main results } & \multirow[t]{3}{*}{16} & $\begin{array}{l}\text { (a) Give unadjusted estimates and, if applicable, } \\
\text { confounder-adjusted estimates and their precision (eg, } \\
95 \% \text { confidence interval). Make clear which } \\
\text { confounders were adjusted for and why they were } \\
\text { included }\end{array}$ & Results \& Table 2 \\
\hline & & $\begin{array}{l}\text { (b) Report category boundaries when continuous } \\
\text { variables were categorized }\end{array}$ & Tables $1-2$ \\
\hline & & $\begin{array}{l}\text { (c) If relevant, consider translating estimates of relative } \\
\text { risk into absolute risk for a meaningful time period }\end{array}$ & NA \\
\hline Other analyses & 17 & $\begin{array}{l}\text { Report other analyses done - eg analyses of subgroups } \\
\text { and interactions, and sensitivity analyses }\end{array}$ & Results \& Tables 3-4 \\
\hline \multicolumn{4}{|l|}{ Discussion } \\
\hline Key results & 18 & Summarise key results with reference to study objectives & Discussion, paragraph 1 \\
\hline Limitations & 19 & $\begin{array}{l}\text { Discuss limitations of the study, taking into account } \\
\text { sources of potential bias or imprecision. Discuss both } \\
\text { direction and magnitude of any potential bias }\end{array}$ & $\begin{array}{l}\text { Discussion ('Limitations and } \\
\text { caveats') }\end{array}$ \\
\hline Interpretation & 20 & $\begin{array}{l}\text { Give a cautious overall interpretation of results } \\
\text { considering objectives, limitations, multiplicity of } \\
\text { analyses, results from similar studies, and other relevant } \\
\text { evidence }\end{array}$ & Discussion, paragraph 1 \\
\hline Generalisability & 21 & $\begin{array}{l}\text { Discuss the generalisability (external validity) of the } \\
\text { study results }\end{array}$ & $\begin{array}{c}\text { Discussion ('Limitations and } \\
\text { caveats') }\end{array}$ \\
\hline \multicolumn{4}{|c|}{ Other information } \\
\hline Funding & 22 & $\begin{array}{l}\text { Give the source of funding and the role of the funders } \\
\text { for the present study and, if applicable, for the original } \\
\text { study on which the present article is based }\end{array}$ & Acknowledgements \\
\hline
\end{tabular}

Abbreviations: NA: not applicable. 
medRxiv preprint doi: https://doi.org/10.1101/2022.03.02.22271771; this version posted March 4, 2022. The copyright holder for this preprint (which was not certified by peer review) is the author/funder, who has granted medRxiv a license to display the preprint in perpetuity.

All rights reserved. No reuse allowed without permission.

\section{References}

1. Multiplexed RT-qPCR to screen for SARS-COV-2 B.1.1.7, B.1.351, and P.1 variants of concern V.3. dx.doi.org/10.17504/protocols.io.br9vm966. 2021. (Accessed June 6, 2021, at https://www.protocols.io/view/multiplexed-rt-qpcr-to-screen-for-sars-cov-2-b-1-1-br9vm966.)

2. Abu-Raddad L, Chemaitelly H, Butt AA, National Study Group for C-V. Effectiveness of the BNT162b2 Covid-19 Vaccine against the B.1.1.7 and B.1.351 Variants. N Engl J Med 2021;385:187-9.

3. Chemaitelly $\mathrm{H}$, Yassine HM, Benslimane FM, et al. mRNA-1273 COVID-19 vaccine effectiveness against the B.1.1.7 and B.1.351 variants and severe COVID-19 disease in Qatar. Nat Med 2021;27:161421.

4. Qatar viral genome sequencing data. Data on randomly collected samples.

https://www.gisaid.org/phylodynamics/global/nextstrain/. 2021. at

https://www.gisaid.org/phylodynamics/global/nextstrain/.)

5. Benslimane FM, Al Khatib HA, Al-Jamal O, et al. One Year of SARS-CoV-2: Genomic Characterization of COVID-19 Outbreak in Qatar. Front Cell Infect Microbiol 2021;11:768883.

6. Hasan MR, Kalikiri MKR, Mirza F, et al. Real-Time SARS-CoV-2 Genotyping by High-Throughput Multiplex PCR Reveals the Epidemiology of the Variants of Concern in Qatar. Int J Infect Dis 2021;112:524.

7. Chemaitelly H, Tang P, Hasan MR, et al. Waning of BNT162b2 Vaccine Protection against SARSCoV-2 Infection in Qatar. N Engl J Med 2021;385:e83.

8. Saththasivam J, El-Malah SS, Gomez TA, et al. COVID-19 (SARS-CoV-2) outbreak monitoring using wastewater-based epidemiology in Qatar. Sci Total Environ 2021;774:145608.

9. World Health Organization. Tracking SARS-CoV-2 variants. Available from: https://www.who.int/en/activities/tracking-SARS-CoV-2-variants/. 2021.

10. Abu-Raddad L, Chemaitelly $\mathrm{H}$, Ayoub HH, et al. Effectiveness of BNT162b2 and mRNA-1273 COVID-19 boosters against SARS-CoV-2 Omicron (B.1.1.529) infection in Qatar. medRxiv In press at New England Journal of Medicine 2022:2022.01.18.22269452.

11. Chemaitelly $\mathrm{H}$, Ayoub $\mathrm{HH}$, Coyle $\mathrm{P}$, et al. Protection of Omicron sub-lineage infection against reinfection with another Omicron sub-lineage. medRxiv 2022:2022.02.24.22271440.

12. Altarawneh $\mathrm{HN}$, Chemaitelly $\mathrm{H}$, Hasan MR, et al. Protection against the Omicron Variant from Previous SARS-CoV-2 Infection. N Engl J Med 2022.

13. Chemaitelly $\mathrm{H}$, Ayoub HH, AlMukdad S, et al. Duration of protection of BNT162b2 and mRNA1273 COVID-19 vaccines against symptomatic SARS-CoV-2 Omicron infection in Qatar. medRxiv 2022:2022.02.07.22270568.

14. Thermo Fisher Scientific. TaqPath ${ }^{\text {TM }}$ COVID-19 CE-IVD RT-PCR Kit instructions for use. Available from: https://assets.thermofisher.com/TFS-Assets/LSG/manuals/MAN0019215 TaqPathCOVID-19 CEIVD RT-PCR\%20Kit IFU.pdf. Accessed on December 02, 2020. 2020.

15. UK Health Security Agency. SARS-CoV-2 variants of concern and variants under investigation in England: Technical briefing 34. England2022. 